\title{
Az online reklámok közvetlen hatásának vizsgálata a vásárlási döntésekre
}

\author{
Korpás Zoltán - Szabó Bálint \\ Budapesti Műszaki és Gazdaságtudományi Egyetem
}

\begin{abstract}
A TANULMÁNY CÉLJA
A tanulmány célja az online reklámok közvetlen vásárlásra tett hatásának vizsgálata egy banner hirdetés példáján keresztül, illetve az alkalmazott módszertan korlátainak feltárása és továbbfejlesztése annak érdekében, hogy az szélesebb körben alkalmazható legyen.
\end{abstract}

\begin{abstract}
ALKALMAZOTT MÓDSZERTAN
A kutatás szemmozgás-követéses technológia segítségével zajlott, amely kérdőíves felméréssel és egy rövid személyes interjúval a márkaszimpátia, az online reklámok, illetve az internetfogyasztással kapcsolatos attitüdök összefüggéseit tárja fel az online reklámok közvetlen, vásárlásra tett hatásával egyetemben.
\end{abstract}

\section{LEGFONTOSABB EREDMÉNYEK}

Az alkalmazott módszertanról kiderült, hogy az megfelelően implementálható a különböző reklámeszközök közvetlen, azonnali vásárlásra tett hatásának mérésére irányuló kísérletekben. Jelen kísérlet esetén a résztvevők fel tudták idézni a hirdetésben látott tartalmat, vagyis a kísérlet igazolja azt, hogy egy reklám elérheti a fogyasztó észlelési küszöbét és átadhatja az üzenetét annak ellenére, hogy a látogatók a bannervakság jelensége miatt sokszor valamilyen módon (tudatosan, vagy félig tudatosan) ignorálják azt. Ezen túl elmondható, hogy a hirdetésre fordított figyelem mértéke (fixációk száma és hossza) csak bizonyos esetekben függ össze pozitívan a reklámozott termék márkaszimpátiájának azonnali változásával. A reklám ismételt megjelenésekor, csak az első fixáció hossza korrelált szignifikánsan, pozitívan a változással. Ellenben, a közvetlen termékválasztás és a reklám megjelenése közötti összefüggés statisztikailag nem volt igazolható, de a kapott eredmények arra utalnak, hogy a módszertan javításával és az elemszám növelésével a hatás kimutatható. Elmondható továbbá, hogy jelen mintában statisztikailag igazolható volt, hogy minél inkább zavarta a résztvevőt a hirdetés jelenléte, annál kevésbé gondolta magát tudatos internethasználónak.

\section{GYAKORLATI JAVASLATOK}

A mobil és online technológiák térhódításának következtében a marketing folyamatos átalakulásban van, éppen ezért a reklámok közvetlen, azonnali hatásának vizsgálata elengedhetetlen az online fogyasztói magatartás mechanizmusainak mélyebb megértése érdekében. Az alkalmazott módszertan sikeresen különíti el az online reklámhatást az egyéb vásárlásra ható változóktól, így az általa kinyerhető eredmények fontos információkkal szolgálhatnak a jövő reklámpiacára vonatkozóan.

Kulcsszavak: online reklám hatékonyság elemzés, bannervakság, szemmozgáskövetés, vásárlási döntési mechanizmusok vizsgálata

DOI: https://doi.org/10.15170/MM.2019.53.02.03 


\section{BEVEZETÉS}

A technológiai fejlődésnek köszönhetően a médiumok közül az internet szerepe meghatározóvá vált, aminek egyértelmü jele a világhálós reklámokra költött összegek jelentős növekedése. Mivel ezekre egyre több vállalat tekint elsődleges kommunikációs lehetőségként (Fazekas - Harsányi 2011), az elmúlt évtizedekben az online reklámok használatát folyamatos növekedés jellemezte (Reketytye és tsai. 2015). Az utóbbi években a digitális hirdetéssel elért globális bevételek növekvő tendenciája többek között a mobil hirdetések kiugró növekedésének köszönhető (PWC 2018), ám a mobileszközök, illetve ezzel együtt a mobilmarketing térnyerése jelentősen megváltoztatta a felhasználók adatfogyasztási szokásait volumen és gyakoriság tekintetében is (Keun et al. 2016). A változás alól Magyarország sem kivétel, hiszen 2017-ben már a lakosság 61\%-a használt okostelefont (Pew 2018). A mobileszközök, illetve -reklámok térnyerése következésképp itthon is hatással van a vásárlási döntési folyamatokra, és mivel a különböző hordozható eszközeink a nap minden pillanatában velünk vannak, így a vásárlói döntéseinkre is azonnali, közvetlen hatással lehetnek. Az online, azonnali reklámhatásnak az offline (személyes) vásárlási szándékra tett befolyása azonban kevéssé vizsgált terület, így a kutatás módszertana az ezzel kapcsolatos ismereteket kívánja tágítani.

\section{SZAKIRODALMI ÁTTEKINTÉS}

A világhálón számtalan reklámformával találkozhatunk, amelyeknek a vállalkozás határozza meg profilját, a reklámcél pedig az alkalmazhatóságát. Ilyenek például a kereséshez kapcsolódó reklámok, vagy a különböző felugró (pop-up) elemek, szalaghirdetések (Kotler, Keller 2012). Ezek közül az internetes szalaghirdetések (bannerek) olyan, a világhálón alkalmazott hirdetési formák, amelyek kattintással juttatják el a felhasználókat a reklámhoz kapcsolt weboldalra (Cohan 2005). Ezek a bannerhirdetéseknek nagymértékben képesek növelni az eladási volument, így szignifikáns hatással lehetnek az internetes és az offline vásárlásra is, ezzel a mai napig megőrizve létjogosultságukat a reklámpiacon (Lewis, Reiley 2014).

A statikus online reklámok alapvető célja az volt, hogy valamely oldalon jelen legyenek, ott vizuálisan felkeltsék a látogatók érdeklődését és átkattintést (Click-Through-t) generálva eljuttassák a felhasználót a hirdető weboldalára, így építve a fogyasztók márkatudatosságát hosszútávon (Rae
- Brennan 1998). A cél természetesen azóta is változatan, de a technológia fejlődésének és a közösségi médiának köszönhetően ezek a reklámok már bárhol képesek jelen lenni. Mivel a reklámterhelés folyamatosan nő, ezért a különféle reklámok hatékonysága jelentősen csökkent, hiszen a reklámimpulzusok döntő része nem jut el az észlelési szintig. Ezt mutatja a 2016-os, Google rendszerén belüli, mindössze 0,19 százalékos globális átkattintási arány (Click-Through Rate), amely Magyarországon még kevesebb, mindössze 0,05 százalék volt.

Ez nem meglepő, hiszen a mai információktól, reklámoktól túlterhelt világunkban rengeteg irreleváns információ bombázza az egyént és ez az internet fejlődésével a virtuális világban is ugyanúgy állandósult. A „vidra effektus” erre a túlterhelésre adott válasz, amely az egyének szintjén, tudat alatt jelenik meg. Ez az effektus azzal jár, hogy az érzékszervek automatikusan lezárják az utat a zavaró mennyiségü ingerkonstellációk előtt, vagyis a reklámok többsége egyszerüen nem éri el az érzékelési küszöböt (Sas 2012). A reklámok befogadhatatlan, túlzott mennyisége jelentősen hozzájárult a reklámkerülés kialakulásához. Rejón \& Martínez (2014) szerint a reklámok által gerjesztett zsúfoltság szubjektív érzetének a fő komponense az online hirdetés „tolakodásának” erejéből fakad. Az erőszakos (például pop-up) reklámok gyakran járulnak hozzá a reklám elutasításához, elkerüléséhez, ezzel csökkentve a hirdetés felidézésének és a vásárlásnak az esélyét. Ezen túl, ezek a reklámok hajlamosabbá teszik a fogyasztókat arra, hogy a reklámok összességével kapcsolatban negatív attitüdök alakuljanak ki bennük (Margarida 2013), így ezt a hirdetési formát kutatásunk nem vizsgálja.

Benway már az internet korai szakaszában felfedezett egy jelenséget, amely igazolta, hogy az emberi agy képes arra, hogy a tudati kontrollt megkerülve védekezzen a modern idők kommunikációs áradata ellen (Sas 2012). Annak ellenére, hogy Benway kísérletében az elvégzendő feladat válasza egy weboldal hirdetésében volt elrejtve, a résztvevők többsége mégis átsiklott az információ felett (Benway \& Lane 1998). Ezt a jelenséget, miszerint az internethasználók egy része nem látja, vagy ignorálja a bannerszerủ információkat bannervakságnak nevezte el. Benway szerint, ha a keresett információ egy nagy, színes és az oldal többi részétől egyértelmủen elkülönülő keretben (reklám formában) helyezkedik el, akkor a látogató nagy esélylyel nem veszi észre. Ellenben, ha a reklám kevésbé különül el perceptuálisan, akkor ez a hatás mérsékelhető (Benway 1999), emiatt a kutatás során cikk közé ékelődő hirdetés lett alkalmazva. 
Briggs és Hollis (1997) kutatásai arra az eredményre jutottak, hogy a reklám puszta látványa is elégséges, mert a hirdetés jelenléte önmagában növeli a vásárlás valószínűségét és az adott márka ismertségét, így használható a márkatudatosság (branding) növelésére. Dreze és Hussherr (2003) kutatásai szintén alátámasztják, hogy annak ellenére, hogy a felhasználók elkerülik a tekintetükkel az online hirdetéseket, a perifériás látásukkal még érzékelhetik azokat, így a bannerek anélkül is kifejthetik befolyásoló erejüket, hogy a felhasználó tekintete egyértelmű interakcióba lépne vele. McCoy és társai (2004) ezzel egybehangzóan úgy érveltek, hogy amíg pop-up reklámok esetén a felhasználók csak annak bezárására fókuszálnak, addig a banner típusú hirdetések sokkal tovább maradnak a látómezőben ezáltal növelve az esélyét annak, hogy a látogató megjegyezze az adott reklám tartalmát. Összegezve, a banner reklámok úgy is képesek lehetnek azonnali reklámhatást kifejteni, hogy csupán a látómezőben helyezkednek el és kevésbé terelik el a résztvevők figyelmét egy adott feladatról.

Rutz és Bucklin (2012) kutatásai alapján kijelenthetô az is, hogy az online reklámok második megjelenése hat a legmarkánsabban a felhasználók viselkedésére. Ez részben egybevág Drèze és Hussherr (2003), illetve Robinson et al. (2007) megállapításaival is, miszerint az internetes hirdetések ismételt megjelenítése elősegíti a márkatudatosság növelését, így a hirdetés jelen kutatásban is többször jelent meg.

Kutatások azt találták a banner hirdetésekkel kapcsolatban, hogyha az abban használt színek a weboldal többi részével nem illenek össze, akkor ugyan több figyelmet kap az adott hirdetés, viszont az negatív hatással lesz az oldalra irányuló felhasználói attitüdre (Moore et al. 2005; Robinson et al. 2007). A kísérletben megjelenő hirdetést az oldaltól elütő színben ábrázoltuk, így vállalva a márka felé esetlegesen kialakuló negatív attitüdöket, a nagyobb láthatóság biztosítása érdekében.

A reklámok láthatósága természetesen nagyban függ attól is, hogy a látogatók milyen tevékenységet folytatnak az adott weboldalon. Célorientált feladatok esetén a felhasználók a bannereket jobban ignorálják, kevésbé ismerik fel és hiányosabban tudják felidézni, mint a böngészési tevékenységek során (Pagendarm \& Schaumburg 2001, Riegelsberger et al. 2002, Yesilada et al. 2008; Owens et al. 2011). A kísérlet során ezen megállapításokat figyelembe véve egy olyan elrendezés lett kiválasztva, amely jól reprezentál egy mindennapi internetes tevékenységet, a cikkolvasást, amely a böngészésnél jobban, de a keresési feladatoknál kevésbé célorientált tevékenységként azonosítható.
A bannervakság tehát egy régóta ismert fogalom a marketing, a reklámpszichológia és a webergonómia területén, de a jelenség vizsgálata még mindig aktuális a hatékony online hirdetések kialakítása érdekében. Mivel a közösségi média elterjedésével az online hirdetési lehetőségek száma megnőtt, így a legújabb kutatások már a különbözü típusú közösségi médiás eszközök hatékonyságát vizsgálják reklámkerülési szempontból (Van den Broeck et. al. 2018, Mattke et al. 2018), vagy a mobilos bannerhirdetések elhelyezésének a hatékonyságát mérik az applikáció típusának a függvényében (Çiçek et al. 2018).

Az online hirdetések a különféle mobilmarketing megoldások népszerüségének köszönhetően már a mindennapi létünk szerves részét alkotják és azonnali hatást fejtenek ki a vásárlási döntésekre. A reklámok azonnali hatásának vizsgálata emiatt fontos kutatási terület és egy viszonylag feltérképezetlen terület a marketing szakirodalmakban.

Jelen kutatás ezért tehát az online reklámok közvetlen, termékválasztásra tett hatásának a vizsgálatára mutat be egy jól adaptálható módszertant, miközben a döntési folyamatban megjelenő egyéb tényezők súlyát is figyelembe veszi.

\section{MÓDSZERTAN}

Az online reklámok tehát igen különböző helyeken, eltérő méretekben, más-más kinézettel és mechanizmussal jelennek meg (Bányai - Novák 2015), amelyek közül jelen kutatás során a vizsgált kísérleti inger az egyik legelterjedtebb online hirdetési formában, bannerként realizálódott (IAB 2016). A reklám megjelenése során fontos szempont volt, hogy a felhasználók pozitív attitüdökkel közelítsenek felé (Kohli et al. 2007). Ha ugyanis egy webes hirdetés leköti (esetleg szórakoztatja) a látogatót, akkor nagyobb eséllyel növeli az átkattintási értéket is.

Emiatt jelen kísérlet középpontjában egy ilyen jellemzőkkel rendelkező TUC (keksz) online banner szerepel ingerként, a kísérleti honlap tartalmi, középső részében elhelyezve, ,cikktörö” jelleggel. A TUC, mint mindennapi fogyasztási termék azért is szerencsés választás, mert alacsony a szubjektív kockázata a vásárlási döntések tekintetében. Ha ugyanis a reklám tartalmának tekintetében a rutin, illetve az impulzusvásárlások (expresszív termékek) felől elmozdulnánk a funkcionális termékek irányába, akkor a fogyasztók értelemszerüen több információt keresnének a végső vásárlási döntés meghozatala előtt (Hofmeister et al. 2003), amelynek már torzító hatása lenne a reklámok közvetlen hatásának vizsgálatában (Dahlén 2002). 
A kutatás legfőbb kérdése, hogy a hirdetés milyen közvetlen hatással van a felhasználókra egy élelmiszer vásárlást szimuláló döntési helyzetben. A fó hipotézis, hogy az online hirdetés pozitívan hat a résztvevök döntésére, vagyis a kísérleti személyek a reklámozott terméket nagyobb valószínűséggel fogják választani a vásárlást szimuláló helyzetben. A hipotézis teljes körü vizsgálata a szemmozgás-követéses rendszer segítségével kinyert különböző nézettségi mutatók, az előzetes és utólagos kérdőívek által szolgáltatott adatok, valamint a strukturált interjúkra adott válaszok segítségével vált lehetővé.

A kísérlet 36 résztvevője 18 és 30 év közötti, 94\%-ban felsőfokú végzettséggel rendelkező személyből állt össze. Az említett minta kizárólag nem szerint került rétegezésre, így a nők és a férfiak 50-50\%-ban képviseltették magukat a kísérleti, illetve a kontroll csoportban. A kísérleti csoportnak megjelent a vizsgált banner, míg kontroll csoportnak semmilyen hirdetés nem jelent meg.

A vizsgálat után a két csoport tagjai négyféle ajándék (TUC Original, Chio Slims, Haribo Goldbären, Oreo Original) közül választhattak a részvételért cserébe. Az ajándékok kiválasztásánál a legfontosabb szempont a termékek külsődleges ismertetőjeleinek, méretének hasonlósága, illetve a sós és édes termékek azonos aránya volt. Az így kiválasztott napi fogyasztási cikkek a webes felületen megjelenő reklámok közvetlen hatásának vizsgálatában ugyan kulcsszerepet töltöttek be, de erről a kísérleti személyek nem lettek tájékoztatva. A résztvevők úgy tudták, hogy a kutatás középpontjában különböző internetes tartalmak olvasási mintázatának a vizsgálata áll, amely így a Tobii T120-as asztali szemmozgás-követéses rendszer alkalmazását is indokolta.

A szemmozgás-követéses technológia lehetővé teszi az érdeklődési (úgynevezett Area of Interest) területek (például bannerek) weboldalon történő kijelölését, amelyekre így különféle számszerüsíthetö mutatók kérhetők le (Holmqvist et al. 2011). A szemmozgások két legfontosabb típusa a fixációk és a szakkádok. A fixációk hosszabb (200-600 ms időtartamú) szemmozgások, amelyek során a tényleges információfelvétel történik és elkezdődik a vizuális bemeneti ingerek kognitív feldolgozása. A szakkádok pedig az ezeket összekötő rövidebb (40120 ms-ig tartó), ballisztikus szemmozgás típusok, amely során szünetel az információfelvétel, így percepció sem zajlik. A kapcsolódó mutatók közül a fixációk darabszáma például az adott AOI-ra vonatkozó fixációk összes mennyiségét határozza meg, a látogatások száma pedig megadja, hogy az adott érdeklődési területekre hány alkalommal vándorolt vissza a kísérleti személyek tekintete (Szabó 2015). Ezek a mutatók így az adott területek szubjektív fontosságát jelzik (Hámornik et al. 2013).

A kutatás első fázisa egy előzetes kérdőív kitöltése volt, amely különböző demográfiai adatokra (nem, kor, aktuális tanulmányok), internetezési szokásokra, attitüdökre (böngészési gyakoriság, eszközhasználat, tudatos internethasználat), illetve a márkaszimpátiára kérdezett rá (Veres et al. 2015).

A kutatás következö fázisa a szemmozgás-követéses vizsgálat, amelynek során három, egymástól eltérő internetes tartalom elolvasása volt a feladat. A hírportálok böngészése és az így megtalált különbözö típusú tartalmak olvasása hozzátartozik az internethasználók jelentős részének mindennapos tevékenységéhez, ezáltal megfelelö terepet biztosít az ott megjelenő reklámok és a felhasználók között végbemenő interakciók vizsgálatára.

A vizsgálat középpontjában szereplő kísérleti inger egy statikus $(800 * 150$ pixeles) TUC keksz banner (1.ábra), amely termék formájában, jutalomként az ajándékok között is realizálódott. Ez a kísérleti csoportnak szánt weboldalon az első és a harmadik cikknél jelent meg, míg a második oldalon egy tartalmában (Top Eleven internetes játék), illetve kinézetében is semleges szalaghirdetés jelent meg (1. ábra), annak érdekében, hogy az élénk színủ kísérleti ingeranyag ne tegye egyértelmúvé a vizsgálat tárgyát. 


\section{1. ábra: A vizsgált ingeranyag megjelenése a kísérleti csoport számára az eltérő tartalmak között}

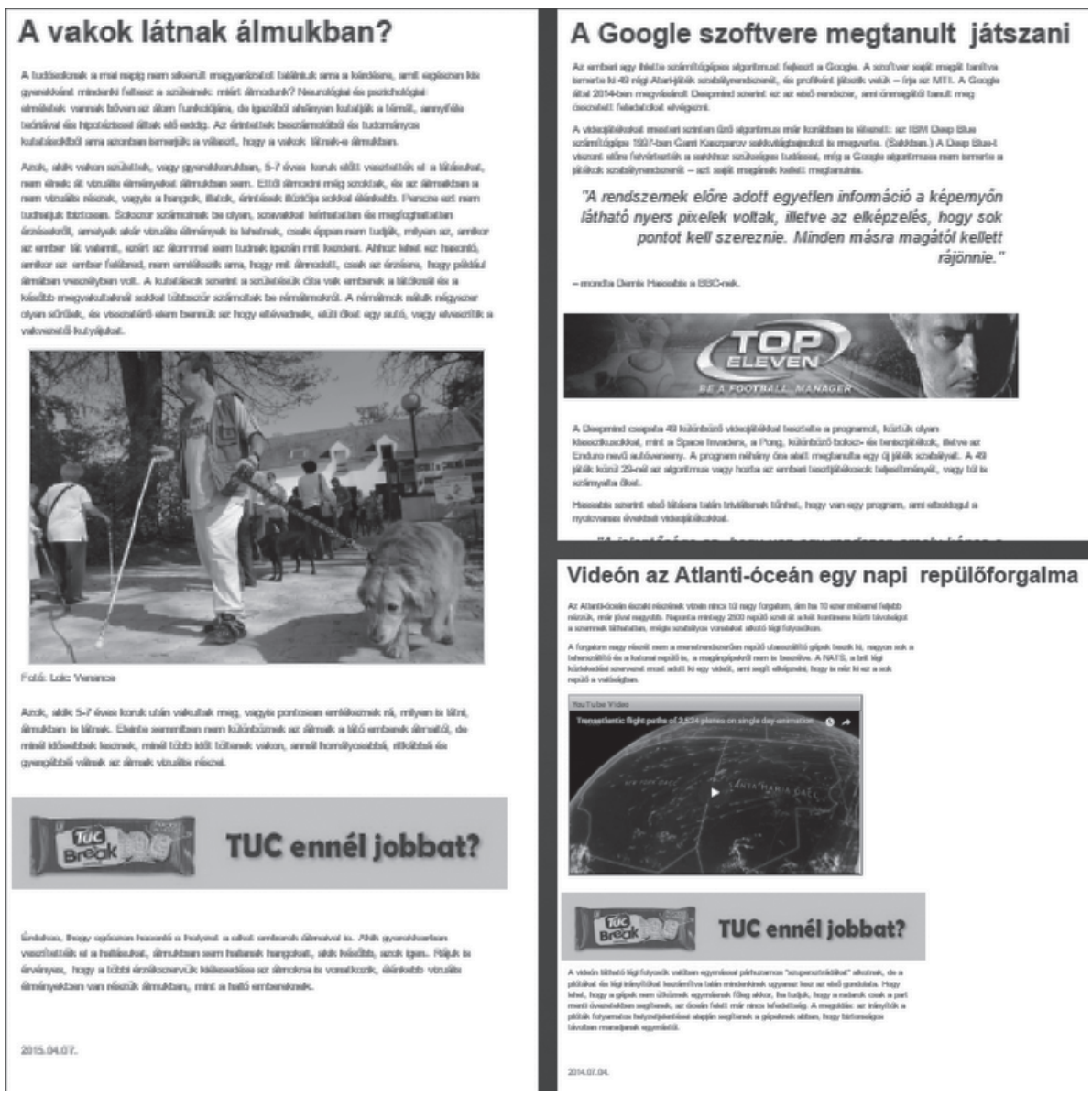

Forrás: saját szerkesztés

A vizsgált ingeranyag tehát egy olyan banner, ami a megjelenésével a termék csomagolásához illeszkedett. Ezzel a megoldással a banner meglehetősen elütött az oldal háttérszínétől, hogy biztosan megragadja a résztvevők figyelmét, míg a banneren szereplő „TUC ennél jobbat?” szlogen egyediséget sugall és lehetővé teszi az adott márka azonosítását, az esetleges pozitív attitüdök kialakításának érdekében.

A kutatás harmadik fázisában a TUC reklám közvetlen hatásának a vizsgálata érdekében a kísérleti személyek négy jutalom közül választhattak a részvételért cserébe. A választás ezen a ponton magát a vásárlási döntést szimulálta, vagyis azt, hogy a kinézetben és árban hasonló termékek közül hogyan választanak a fogyasztók. A kutatás legfőbb kérdése, hogy a kísérleti csoportban szignifikánsan többen választják-e a hirdetés hatására a kísérleti ingerben szereplö konkrét terméket (TUC) vagy a sós ízeket (TUC vagy Chio), mint a kontroll csoportban.

A kutatás negyedik fázisában két újabb kérdőívet kellett kitöltenie a résztvevőknek. Az első kérdéssorban három szövegértési feladatot kellett megválaszolni, amely az olvasott tartalmakra vonatkozott, annak érdekében, hogy elterelje a 
figyelmet a kutatás tényleges tárgyáról, illetve hogy vizsgálható lehessen, hogy a cikkek feldolgozásának mértékére milyen hatással vannak az online hirdetések. ${ }^{1}$ A második kérdöív ellenben ugyanazokat a márkaszimpátiával kapcsolatos kérdéseket tartalmazta, amelyeket az első kérdőív is, így tehát megtörtént az előzetes állapotfelmérés megismétlése, hogy ezáltal kvantitatív módon mérhetővé váljon a márkaszimpátia változása a kísérleti inger hatására (Veres et al. 2006).
A kísérlet utolsó fázisában interjúkérdések hangzottak el a résztvevők felé, amelyek a termékválasztással kapcsolatos attitüdökre vonatkoztak. A kísérleti csoport esetén az is szóba került, hogy mely hirdetések tudatosultak bennük és hogy menynyire találták zavarónak azokat. Ezáltal vizsgálhatóvá vált, hogy van-e bármilyen különbség azon személyek között, akik észrevették a reklámokat és azok között, akik nem. Itt a hirdetés tudatosulásának a mértéke aszerint határozható meg, hogy a résztvevők milyen alapossággal tudják előhívni a memóriájukból az oldalakon megjelenő reklámokat.

\section{2. ábra: Kutatási terv}

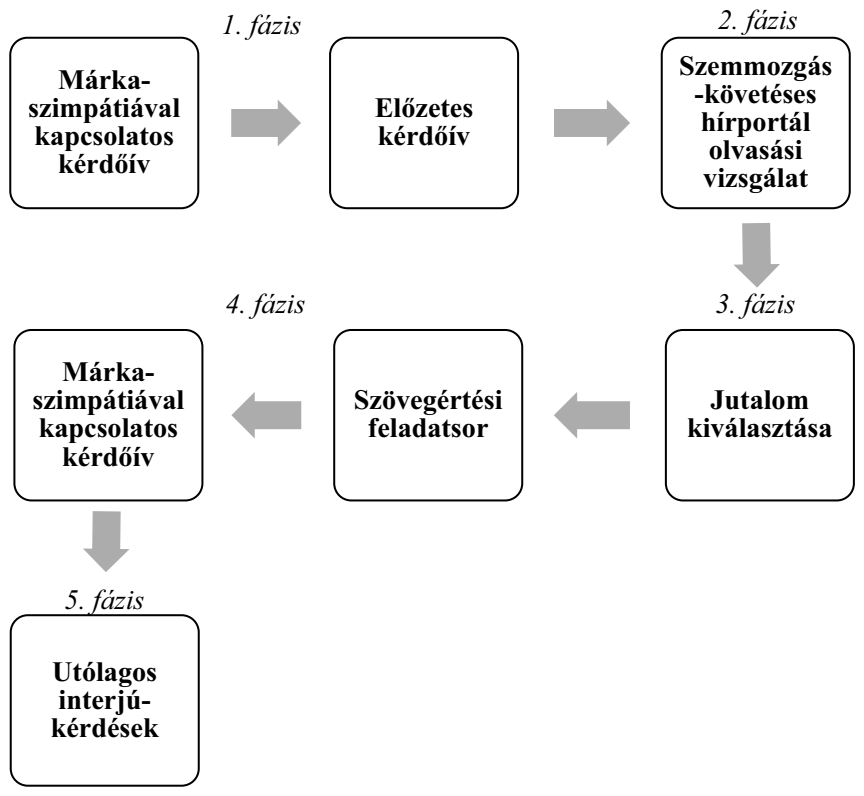

Forrás: saját szerkesztés

A 2. ábrán bemutatott módszertan komplex módon teszi lehetővé az online reklámok és a reklámelkerülés jelenségének a vásárlási döntésekre tett közvetlen, azonnali hatásainak a vizsgálatát, amellett hogy alkalmazásával számos más kapcsolódó hipotézis is vizsgálható.

1. Hipotézis: A hirdetésre fordított figyelem mértéke pozitívan függ össze a reklámozott termékkel kapcsolatos szimpátiapontszám változásával.
2. Hipotézis: A kísérleti csoportban szignifikánsan nagyobb arányban választják a reklámozott terméket (vagy íztípust) a kontrollcsoporthoz képest.

3. Hipotézis: A hirdetésre fordított figyelem mértéke pozitívan függ össze a reklámozott termék választásával. Vagyis minél nagyobb figyelmet kap a kísérleti inger annál nagyobb hatást tesz a reklámozott termék (vagy íztípus) választásra.

Az első hipotézis a kérdőívek, illetve a szemkamera adatainak a segítségével vizsgálható, míg

1 Nem volt kimutatható összefüggés a reklámok jelenléte és a felszínesebb olvasás között. 
a második a termékválasztások ismeretének következtében elemezhető. A harmadik pedig egyaránt épít a termékválasztásokra és a szemmozgás-követéses információkra.

Jelen cikk középpontjában tehát az online reklámoknak a közvetlen fogyasztói viselkedésre tett hatásainak a vizsgálata áll, amely utat mutathat egy olyan kutatási terv felé, amely a különböző marketingmérések során hatékonyan adaptálható az online reklámok közvetlen hatásának vizsgálatára.

\section{EREDMÉNYEK}

Az utólagos interjún elhangzott válaszok alapján elmondható, hogy a résztvevők többsége a kísérleti ingert észrevette. A kísérleti csoportban található 18 főből mindössze 2 személy volt, aki nem tudta megnevezni a megjelenő (TUC) márkát, és közülük is csak 1 résztvevő állította azt, hogy nem látott egyetlen reklámot sem. Ellenben a semleges ban- ner (Top Eleven) esetében a résztvevők több mint fele (11 fö) egyáltalán nem vette észre a hirdetést és csak 3 személy tudta pontosan felidézni a hirdetett márkát. A kapott eredmények értelmezését a szemmozgáskövetéses rendszerből kinyerhető vizuális visszajelzések (hőtérképek) is segítették, amelyeken jól látható, hogy a hirdetésekre alig néztek rá a résztvevők. A 3. ábrán látható, hogy a kísérleti személyek nagyon alaposan olvasták végig a tartalmakat, azonban összességében kevés figyelmet fordítottak a reklámingerekre. Az emlékezet-mérés során a TUC sikeressége a semleges bannerrel szemben következőknek tudható be: a TUC mint termék ismertebb, a márkaneve rövidebb, a hirdetés maga figyelemfelkeltőbb. Emellett elmondható az is, hogy ez a hirdetés többször jelent meg és a TUC, mint márka az előzetes és az utólagos kérdőívben is szerepelt, amely megkönnyíthette a felidézést.

\section{3. ábra: Az első cikkrôl készült összesített hőtérkép a kísérleti csoportban}

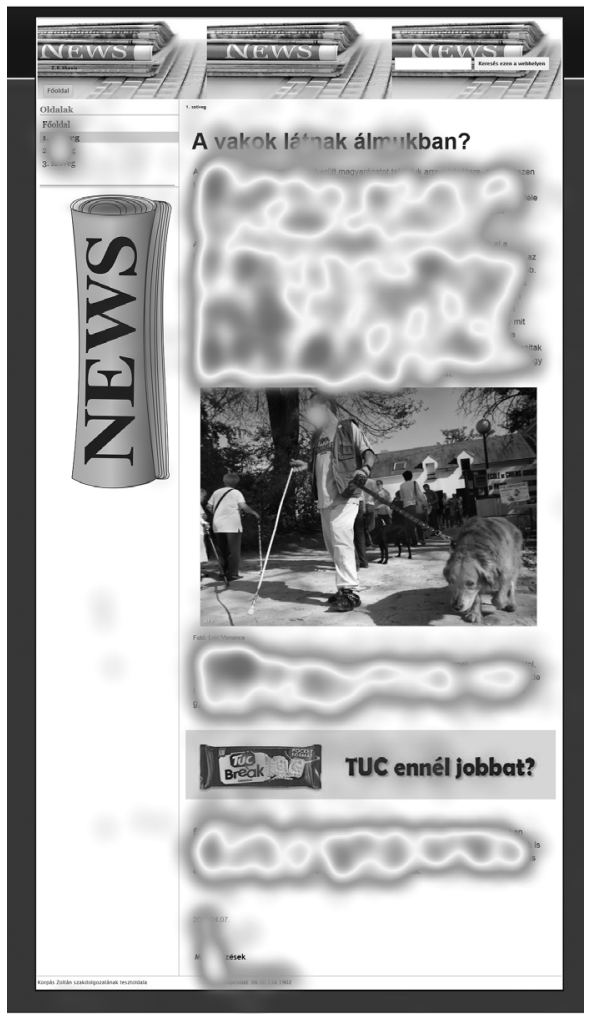

Forrás: saját szerkesztés 


\section{1. táblázat: Az első fixációk hosszának márkaszimpátiával való összefüggésének korrelációs táblája}

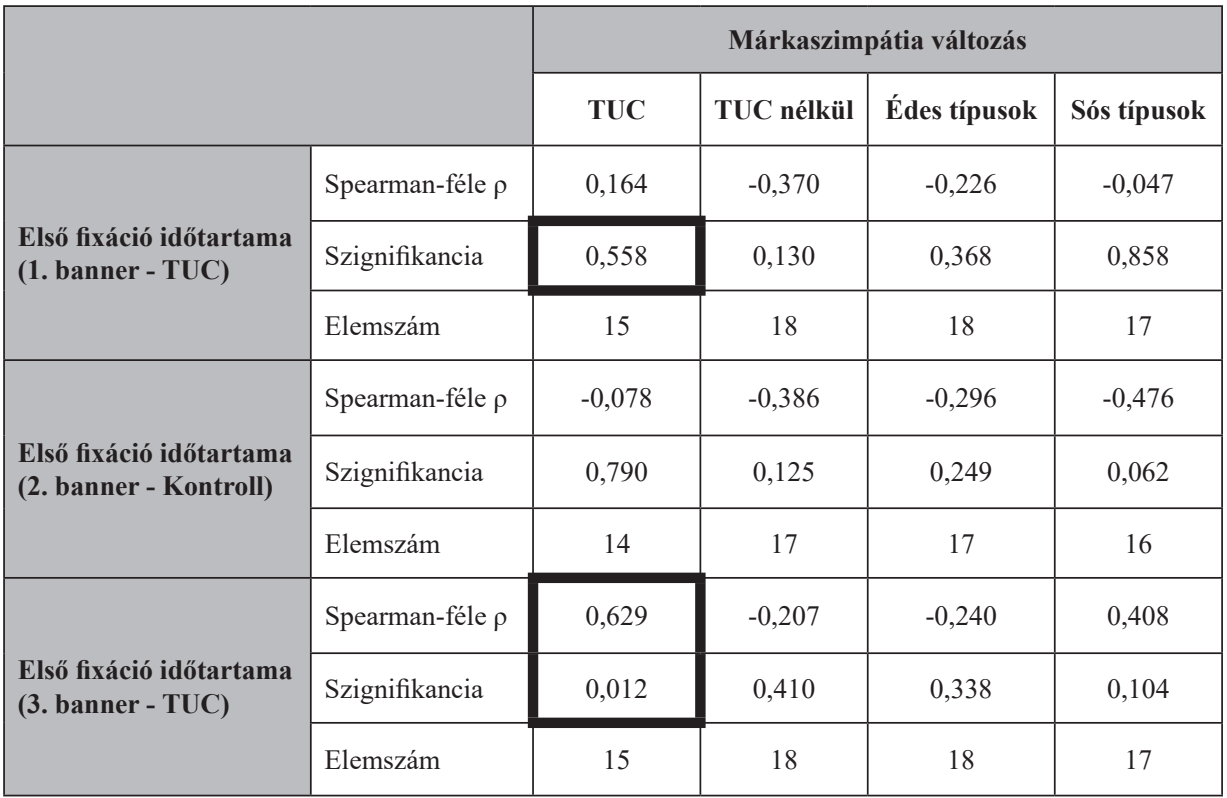

Forrás: saját szerkesztés

$\mathrm{Az}$ 1. hipotézis ellenőrzésére a szemkövetéses szenzor által gyüjtött adatok márkaszimpátiára tett hatása került elemzésre az első fixáció hossza és a márkaszimpátia közti korrelációs tábla segítségével (1. táblázat).

A korrelációs tábla alapján az első TUC banner első fixációjának ideje nem korrelál sem a TUC, sem a sós termékek márkaszimpátiájának változásával. Ellenben a harmadik (kísérleti inger) hirdetés $\rho=0,629$-es erősséggel korrelál a TUC márkaszimpátiájának változásával, vagyis minél hosszabb volt az első fixáció ideje a második TUC banneren, annál inkább változott pozitív irányba a TUC márkaszimpátiája. A második banner erősebb hatása jól illeszkedik a Dahlén (2002) által tett megállapításba is, miszerint az expresszív csoportba tartozó termékek esetén az online hirdetések lassan, több megjelenés után egyre inkább növelik a pozitív attitüdöket a márka felé, de alacsony megjelenési gyakoriságnál ez a hatás elenyésző. A sós termékek márkaszimpátiájának változása és az első fixáció ideje között viszont nem volt értelmezhető összefüggés.

A kísérlet résztvevőinek reklámra irányuló figyelme azonban más perspektívával is értelmezhető, amely a 2. táblázatban látható, ahol a fixációk teljes ideje és a márkaszimpátia közti korrelációk jelennek meg. 


\section{2. táblázat: A fixációk összes időtartama márkaszimpátiával való összefüggésének korrelációs táblája}

\begin{tabular}{|l|l|c|c|c|c|}
\hline \multirow{2}{*}{} & & \multicolumn{4}{|c|}{ Márkaszimpátia változás } \\
\cline { 3 - 6 } & & TUC & TUC nélkül & Édes típusok & Sós típusok \\
\hline \multirow{4}{*}{$\begin{array}{l}\text { A fixáció teljes időtartama } \\
\text { (1. banner - TUC) }\end{array}$} & Spearman-féle $\rho$ & $-0,474$ & 0,081 & 0,268 & $-0,616$ \\
\cline { 2 - 6 } & Szignifikancia & 0,074 & 0,748 & 0,283 & 0,008 \\
\cline { 2 - 6 } & Elemszám & 15 & 18 & 18 & 17 \\
\hline \multirow{2}{*}{$\begin{array}{l}\text { A fixáció teljes időtartama } \\
\text { (2. banner - Kontroll) }\end{array}$} & Spearman-féle $\rho$ & $-0,128$ & $-0,043$ & $-0,075$ & $-0,287$ \\
\cline { 2 - 6 } & Szignifikancia & 0,663 & 0,870 & 0,776 & 0,280 \\
\cline { 2 - 6 } & Elemszám & 14 & 17 & 17 & 16 \\
\hline \multirow{3}{*}{$\begin{array}{l}\text { A fixáció teljes időtartama } \\
\text { (3. banner - TUC) }\end{array}$} & Spearman-féle $\rho$ & 0,023 & 0,068 & 0,113 & 0,001 \\
\cline { 2 - 6 } & Szignifikancia & 0,935 & 0,789 & 0,656 & 0,998 \\
\cline { 2 - 6 } & Elemszám & 15 & 18 & 18 & 17 \\
\hline
\end{tabular}

Forrás: saját szerkesztés

A 2. táblázat alapján az első bannerre eső fixációk teljes ideje 0,008-as szignifikanciával és $\rho=-0,616$ együtthatóval függ össze a sós termékek márkaszimpátiájának változásával. Ez azt jelenti, hogy minél több időt töltött a résztvevő az első reklám nézésével, annál negatívabb irányba változott a sós termékekkel kapcsolatos véleménye. A TUC márkaszimpátiájának változásával nem volt szignifikáns a korreláció, de az adatok ugyanúgy a negatív korreláció irányába mutattak. A kiugró értékek eltávolítása után azonban a fent említett korrelációk eltüntek, tehát a fixációk teljes ideje és a márkaszimpátia között nem volt kimutatható általános összefüggés. Itt még érdemes figyelembe venni az adatok tendenciáját, miszerint a reklámok azon személyek márkaszimpátiájának a változására voltak elsődlegesen negatív hatással, akik sokáig nézték az első hirdetést. Az interjúk során elhangzott válaszok alapján a kapott eredmények a banner szembeszökő (sárga) színével magyarázhatók. A második TUC reklám azonban már kevésbé vonta el a kísérleti személyek figyelmét a feladatról, ami magyarázza, hogy ott miért nem szignifikáns a korreláció.
A fixációk mennyiségével és a „Kilépések / Belépések" számával a vizsgálat nem tárt fel semmilyen jelentős összefüggést.

Összességében megállapítható, hogy az első hipotézis igaznak bizonyult, hiszen a második reklámra eső első fixáció ideje szignifikánsan, pozitívan korrelált a márkaszimpátia változással. Mivel azonban a résztvevők „figyelme” több különböző módon ragadható meg, így lehet olyan figyelmet jelző mérőszám (például a fixációk teljes hossza), amely épp a negatív attitüdök jelenlétekor kap nagyobb hangsúlyt. 


\section{4. ábra: A termékválasztások összegzése a kontroll és kísérleti csoportban}

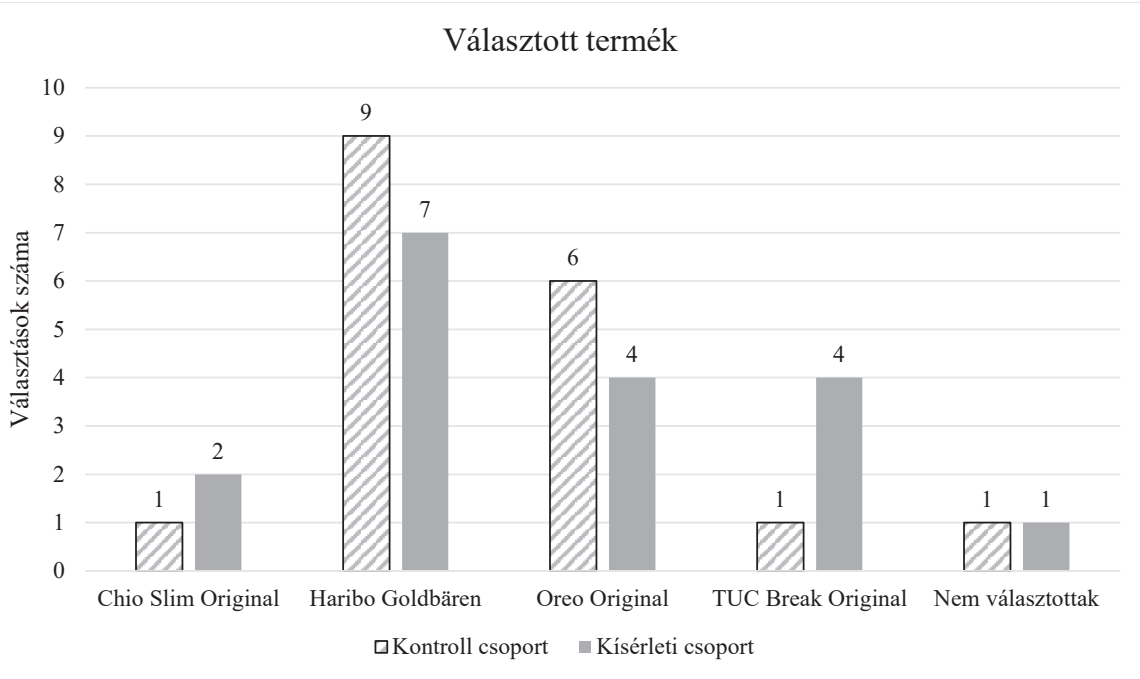

Forrás: saját szerkesztés

A 4. ábrán látható, hogy jelen vizsgálati körülmények között a kísérleti csoportban többen választották a kísérleti ingerként szereplő TUC kekszet jutalomként, mint a kontroll csoportban, azonban a két csoport között nem volt kimutatható szignifikáns különbség. A TUC termék választására 0,241es erösségü korreláció volt kimutatható 0,157 -es szignifikancia szint mellett. Itt a Mann-Whitney féle U és a Kruskal-Wallis teszt szintén nem jelzett szignifikáns különbséget.

A 2. hipotézisre, miszerint a reklámok közvetlen hatással vannak a vásárlói döntésre jelen mintán nem találtunk szignifikáns bizonyítékot. Ellenben megfigyelhetö, hogy a sós (TUC, illetve a Chio) termékek választása magasabb volt a kísérleti csoportban $\rho=0,277$-es, $p=0,112$-es értékek mellett. Ez arra enged következtetni, hogy a hipotézis magasabb elemszám esetén helyesnek bizonyulhat az íztípusra (sós) vonatkozóan is.

A 3. hipotézis nem volt bizonyítható jelen mintán, így a nullhipotézis került elfogadásra, vagyis, hogy a hirdetésre fordított figyelem mértéke nem függ össze pozitívan a reklámozott termék választásával.

További eredményként elmondható, hogy minél inkább zavart valakit egy hirdetés, annál alacsonyabbra értékelte magát szubjektíven a tudatos internethasználói skálán. Az összefüggés szignifikáns $(\mathrm{p}=0,000)$, negatív és erőteljes $(\rho=-0,783)$ korrelációs együtthatóval. Ez magyarázható azzal, hogy egy magát tudatos internethasználónak tartó személy inkább van tisztában azzal, hogy az oldalak fenntartásához a szükséges „rosszat” a reklámok jelentik, mint egy kevésbé tudatos felhasználó.

\section{ÖSSZEFOGLALÁS}

Összességében elmondható, hogy a bemutatott módszertan jól alkalmazható az online reklámok közvetlen hatásainak a mérésére, hiszen az expresszív termékek ajándékként és egyben kísérleti ingerként történő reprezentálása, illetve a kísérlet natívabb, hírolvasást imitáló elrendezése sikeresen modellezte az élelmiszervásárlási döntési helyzetet.

Abban a csoportban, ahol megjelent a banner, ott többen (4 fö) választották a kísérleti ingerként szereplö TUC kekszet jutalomként, mint a kontroll csoportban (1 fö). Azonban jelen mintán a két csoport között nem volt kimutatható szignifikáns különbség. Elmondható az is, hogy a sós (TUC és Chio) termékek választása magasabb volt a kísérleti csoportban (ott 6 fő választotta a sós ízvilágot, míg a kontroll csoportban 2 személy).

A kísérleti csoportban a 18 föből mindössze 2 személy volt, aki utólag nem tudta megnevezni a megjelenő TUC márkát, és közülük is csak 1 résztvevő állította azt, hogy nem látott egyetlen reklámot sem. A megjelenő semleges bannert viszont már a résztvevők több mint fele nem vette észre. Ez 
jelen vizsgálatban jól magyarázható azzal, hogy a TUC márka jóval ismertebb és a hirdetés megjelenése lényegesen figyelemfelkeltőbb.

A felállított hipotézisek közül az első igaznak bizonyult, a szemmozgás-követéses kvantitatív információk alapján elmondható, hogy az oldalon megjelenő második TUC hirdetésre eső első fixáció ideje szignifikánsan, pozitívan korrelált a kérdőíves megkérdezés segítségével mért márkaszimpátia változással.

A második és harmadik hipotézis nem került elfogadásra, így arra, hogy reklámok közvetlen hatással vannak a vásárlói döntésre, valamint, hogy a hirdetésre fordított figyelem mértéke pozitivan függ össze a reklámozott termék választásával jelen mintán nem találtunk szignifikáns bizonyítékot.
Elmondható az is, hogy az eredmények kiértékelése után különböző kutatási korlátok váltak egyértelművé, amelyek ismertetése segíti a későbbi, hasonló vizsgálatokat a megfelelő kutatási terv kialakításában.

A vizsgálat során kiderült, hogy a márkaszimpátia és a vásárlói döntés ugyanazon kísérleten belüli és egy időben történő mérése nem célszerű. Az elözetes kérdőív márkaszimpátiával kapcsolatos kérdése felhívta a figyelmet a kísérleti ingerre, annak ellenére, hogy abban az irreleváns márkák szimpátiájának felmérése is megtörtént. A torzító hatások minimalizálása érdekében szükség van a kutatási terv kismértékủ módosítására, hogy abban meg tudjon valósulni a márkaszimpátia előzetes, időben is elkülöníthető mérése (5. ábra).

\section{5. ábra: Módosított kutatási terv}

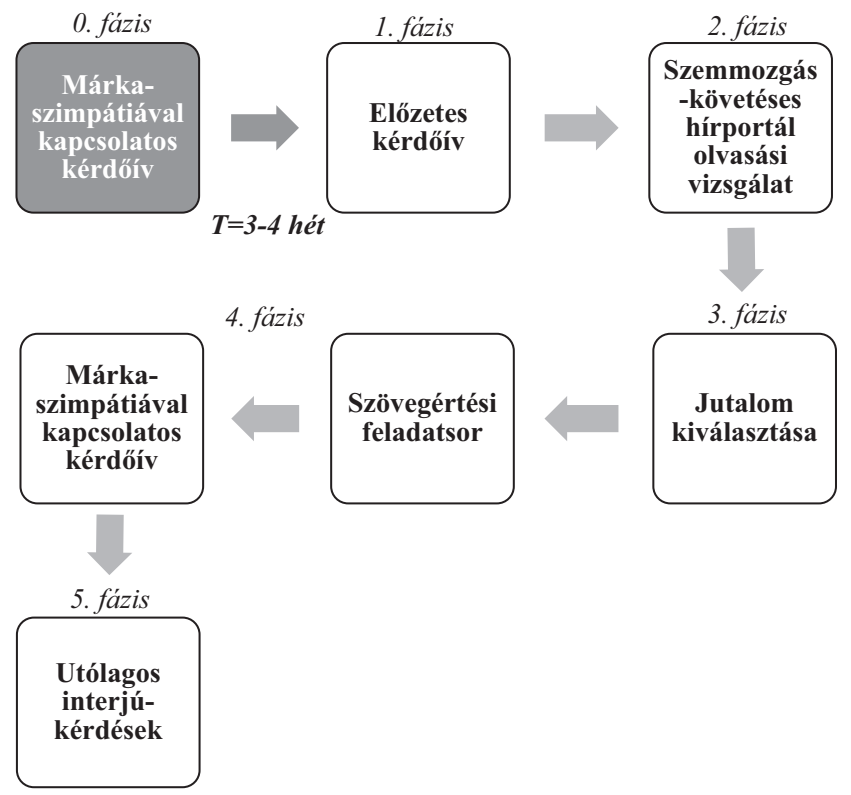

Forrás: saját szerkesztés

Ezen túl, a vizsgálat lezárultával egyértelmüvé vált az is, hogy a résztvevők többsége az édes ízeket preferálja, amely az alacsony mintaelemszám miatt akadályozta a sós típusú kísérleti inger hatásának egzakt mérését. Ez egyszerüen kiküszöbölhető, ha a kísérlet nem méri a sós és az édes közötti preferencia sorrendet, hanem kizárólag az azonos ízvilágú, hasonló árkategóriájú és kinézetű termékek közötti vásárlói döntést vizsgálja. Végezetül, javasolt egy létező és ismert hírportál kinézetre azonos másán megjeleníteni a kísérleti ingert a legtermészetesebb hatás elérése érdekében, amely a kísérleti elrendezést még pontosabbá teheti. 


\section{HIVATKOZÁSOK}

Bányai E. - Novák P. (2015), Online üzlet és marketing, Budapest: Akadémiai Kiadó

Benway, J. P. (1999), "Banner blindness: What searching users notice and do not notice on the World Wide Web". In: Electronic Theses and Dissertations, Houston, Texas: Rice University

Benway, J. P. and Lane, D. M. (1998), Banner Blindness: Web Searchers Often Miss 'Obvious'Links, Houston, TX, Rice University

Briggs, R. and Hollis, N. (1997), "Advertising on the Web: Is There Response before Click-Through?", Journal of Advertising Research, 372 33-45

Çiçek, M., Eren-Erdoğmuş, İ. and Daştan, İ. (2018), "How to increase the awareness of in-app mobile banner ads: exploring the roles of banner location, application type and orientation", International Journal of Mobile Communications, 16 2, 153-66 DOI: https://doi.org/10.1504/ ijmc.2018.10007906

Cohan, W. A. (2005), The marketing plan. 5/e, Hoboken, NJ: Wiley

Dahlén, M. (2002), "Thinking and feeling on the World Wide Web: the impact of product type and time on World Wide Web advertising effectiveness", Journal of Marketing Communications, 8 2, 115-125 DOI: https://doi. org/10.1080/13527260210142347

Drèze, X. and Hussherr, F. X. (2003), 'Internet advertising: Is anybody watching?", Journal of interactive marketing, 17 4, 8-23 https://doi. org/10.1002/dir.10063

Fazekas I. - Harsányi, D. (2011), Marketingkommunikáció érthetően, Második kiadás, Budapest: Szókratész Külgazdasági Akadémia

Hámornik B. P. - Hlédik E. - Józsa E. - Lógó E (2013), „Termékattribútumok vizuális keresése tejtermékek csomagolásán: az érdeklődési övezetek (AOI) kijelölésének két módszerének összehasonlítása", Marketing és Menedzsment 47 3, 43-52

Hofmeister, T. Á. - Simon, J. - Sajtos, L. (2003), Fogyasztói elégedettség, Budapest: Alinea Kiadó

Holmqvist, K., Nyström M., Andersson R., Dewhurst R., Jarodzka H. and Weijer J. (2011), Eye Tracking: A comprehensive guide to methods and measures, Oxford: University Press

IAB (2016), Internet advertising revenue report. https://www.iab.com/wp-content/ uploads/2016/04/IAB-Internet-Advertising-Revenue-Report-FY-2015.pdf (Letöltve: 2019.08.01.)
Keun W. L., Secci, S., Tabourier, L. and Tebbani, B. (2016), "Characterizing and predicting mobile application usage", Computer Communications, 95 1, 82-94 DOI: https://doi.org/10.1016/j.comcom.2016.04.026

Kohli, C., Leuthesser, L. and Suri, R. (2007), "Got slogan? Guidelines for creating effective slogans", Business Horizons, 50 5, 415-22 DOI: https://doi.org/10.1016/j.bushor.2007.05.002

Kotler, P. and Keller, K. L. (2012), Marketing management, 14/e, Upper Saddle River, NJ: Prentice Hall

Lewis, R. A. and Reiley, D. H. (2014), ”Online Ads and Offline Sales: Measuring the Effects of Retail Advertising via a Controlled Experiment on Yahoo!", Quantitative Marketing and Economics, 12 3, 235-66 DOI: https://doi.org/10.1007/ s11129-014-9146-6

Margarida, B. A. (2013), 'Do users look at banner ads on Facebook?", Journal of Research in Interactive Marketing, 7 2, 119-39 DOI: https://doi. org/10.1108/jrim-mar-2012-0013

Mattke J., Müller L., Maier C. and Graser H (2018), "Avoidance of Social MediaAdvertising:ALatent Profile Analysis", Conference on Computers and People Research (SIGMIS-CPR'18), 50-57 DOI: https://doi.org/10.1145/3209626.3209705

McCoy, S., Everard, A., Galletta, D. and Polak, P. (2004), "A Study of the Effects of Online Advertising: A Focus on Pop-Up and In-Line Ads", Proceedings of the Third Annual Workshop on HCI Research in MIS, 50-4

Moore, R. S., Stammerjohan, C. A. and Coulter, R. A. (2005), "Banner Advertiser: Web Site Context Congruity and Color Effects on Attention and Attitudes", Journal of Advertising, 34 2, 71-84 DOI: https://doi.org/10.1080/00913367.2005.10 639189

Owens, J. W., Chaparro, B. S. and Palmer, E. M. (2011), "Text Advertising Blindness: The New Banner Blindness?', Journal of Usability Studies, 6 3, 172-197

Pagendarm, M. and Schaumburg, H. (2001), "Why Are Users Banner-Blind? The Impact of Navigation Style on the Perception of Web Banner", Journal of Digital Information, 21

Pew Research Center (2018), Social Media Use Continues to Rise in Developing Countries but Plateaus across Developed Ones, http://www. pewglobal.org/2018/06/19/social-media-usecontinues-to-rise-in-developing-countries-butplateaus-across-developed-ones/ (Letöltve: 2019.08.01.) 
PWC (2018), Perspectives from the global entertainment 2018-2022, https://www.pwc.com/ gx/en/entertainment-media/outlook/perspectives-from-the-global-entertainment-and-media-outlook-2018-2022.pdf (Letöltve: 2019.08.01.)

Rae, N. and Brennan, M. (1998), 'The relative effectiveness of sound and animation in Web banner advertisements", Marketing Bulletin, 9, 76-82

Rejón, G. F. and Martínez, L. F. J. (2014), ”Online advertising intrusiveness and consumers' avoidance behaviors", Handbook of Strategic E-Business Management, 565-86 DOI: https://doi. org/10.1007/978-3-642-39747-9 23

Rekettye G. - Törőcsik M. - Hetesi E. (2015), Bevezetés a marketingbe, Budapest:Akadémiai Kiadó DOI: https://doi.org/10.1556/9789630597593

Riegelsberger, J., Sasse, M. A. and McCarthy, J. D. (2002), "Eye-Catcher or Blind Spot? The Effect of Photographs of Faces on E-Commerce Sites", Proceedings of the IFIP Conference on Towards The Knowledge Society: E-Commerce, E-Business, E-Government, 383-398

Robinson, H. , Wysocka, A. and Hand, C. (2007), "Internet advertising effectiveness: the effect of design for click-through rates for banner ads", International Journal of Advertising: The Review of Marketing Communications, 26 4, 527-541

Rutz, O. J. and Bucklin, R. E. (2012), ’Does banner advertising affect browsing for brands?", Quantitative Marketing and Economics, 10 2, 231-257 DOI: https://doi.org/10.1007/s11129-011-9114-3

Sas I. (2012), Reklám és pszichológia a webkorszakban, Budapest: Kommunikációs Akadémia

Szabó B. (2015), „Rivalizáló reklámok hatásainak szemmozgáskövetéses pilot vizsgálata dinamikus AOI funkció segítségével", EMOK tanulmánykötet, 21 1, 356-64
Van den Broeck, E., Poels, K. and Walrave, M. (2018), "An experimental study on the effect of ad placement, product involvement and motives on Facebook ad avoidance", Telematics and Informatics, 35 2, 470-9 DOI: https://doi. org/10.1016/j.tele.2018.01.006

Veres Z. - Hoffmann M. - Kozák Á. (2016), Bevezetés a piackutatásba, Budapest: Akadémiai Kiadó DOI: https://doi.org/10.1556/9789634540038

Yesilada, Y., Jay, C., Stevens, R. and Harper, S. (2008), "Validating the Use and Role of Visual Elements of Web Pages in Navigation with an Eye-Tracking Study", Journal of Usability Studies, 17th international conference on World Wide Web, 11-20 DOI: https://doi. org/10.1145/1367497.1367500 
Szabó Bálint, tudományos segédmunkatárs szabobalint@erg.bme.hu Budapesti Müszaki és Gazdaságtudományi Egyetem Gazdaság- és Társadalomtudományi Kar Ergonómia és Pszichológia Tanszék

\section{Investigating the Direct Effects of Banner Blindness on Purchasing Decisions}

\section{THE AIM OF THE PAPER}

The purpose of the study is to examine the effect of online advertising on direct purchases through an example of banner advertising and to explore and further develop the methodology used, to make it more widely applicable.

\section{METHODOLOGY}

The research was carried out using eye-tracking technology, which explores the relationship between brand sympathy, online advertising, Internet-related attitudes and the online advertisements effect on shopping, through a questionnaire and a short personal interview.

\section{MOST IMPORTANT RESULTS}

The methodology used has proven itself implementable in measuring the impact of different advertising devices on direct, immediate purchases. The results show the participants can recall the content of the seen advertisements. So the experiment confirms that the advertisement can reach the perception threshold and increase brand awareness even if the users ignore them in some sort (conscious or half-conscious) because of the banner blindness phenomena. Moreover, the degree of attention (number and length of fixations) paid to the advertisement is positively correlated with the advertised product's brand sympathy only in some peculiar cases. On the other hand, the relationship between direct product selection and the appearance of advertisement was not statistically verifiable, but the results indicate that, by improving the methodology and increasing the sample size, the deviation is likely to be significant. It can also be stated that in this sample it was statistically justifiable that the more annoyed the participant was because of the presence of the advertisement, the less he thought himself a conscious internet user.

\section{RECOMMENDATIONS}

Marketing is constantly evolving due to the development of mobile devices and the underlying technology's penetration, and therefore the investigation of the direct impact of advertisements is important for a deeper understanding of online consumer behavior, therefore the methodology used and the results that can be obtained by it can become quite important in the future of advertising market. As a result of the proliferation of mobile and online technologies, marketing is undergoing a continuous transformation. This is the reason why studying the direct, immediate effects of advertisements are essential for a deeper understanding of the mechanisms of online consumer behavior. The methodology used separates the online advertising effect from the other variables which are affecting the purchases. Consequently the results which can be obtained by it can provide important insight into the future of advertising market.

Keywords: online advertising effectiveness, banner blindness, eye movement tracking, consumer decision making mechanisms 